\title{
Territorial Development - Managing for Sustainability in Brazil
}

\author{
Osvaldo Martins \\ E-mail: osvaldo-martins@live.com \\ Arnoldo José de Hoyos Guevara \\ E-mail: arnoldodehoyos@yahoo.com.br \\ Diego de Melo Conti \\ E-mail: diegoconti@uol.com.br \\ Telma Gonçalves Cunha \\ School of Economics and Business Administration, Pontifical \\ Catholic University of São Paulo, Brazil \\ E-mail: telmagnvs@gmail.com
}

\begin{abstract}
In this study, emphasis will be given to the challenge of the organizational management process within a development model that considers the territorial possibilities and necessities as a basis for the process of sustainable, endogenous development. The territorial unit considered in the study is the municipality, highlighting the existing possibility in Brazil of implanting a model of participatory management on taking into account the large number of small municipalities existing in the Country. The problematic of large cities is also analyzed, recognizing, however, the greater difficulty of articulation among the representative players of society, based on the exogenous forces engaging within these regions. In order to study the management process, the contexts that support the concept of sustainable development and the form of organizing the economic activities will be defined. In the discussion of management properly stated, emphasis will be given to administrative decentralization and to articulation, to planning process and to dissemination of information.
\end{abstract}

Key Words: territorial management; articulation; planning; sustainability.

\section{Territorial development}

The study on the possibility of territorial development being considered, as an alternative to the centralized model of public management for countries like Brazil, seems pertinent based on the contrasts encountered within this territory such as, rich industrial development centers neighboring shanty towns, a powerful agro-industry neighboring or occupying deforested areas, 
a large area of forests with great wealth in terms of biodiversity to be scientifically explored and physically preserved, which demonstrates the diversified scenario of potentialities and needs to be identified and managed.

Brazil embodies an area of approximately 8.5 million $\mathrm{km}^{2}$, which can be divided into six different biomes, according to IBGE (Brazilian Institute of Geography and Statistics) publication:

\begin{tabular}{c|c|c} 
Brazilian Continental Biomes & Approximate Area $\left(\mathrm{Km}^{2}\right)$ & Area/ Total Brazil \\
\hline AMAZÔNIA Biome & $4,196,943$ & $49.29 \%$ \\
\hline CERRADO Biome & $2,036,448$ & $23.92 \%$ \\
\hline MATA ATLANTICA Biome & $1,110,182$ & $13.04 \%$ \\
\hline CAATINGA Biome & 844,453 & $9.92 \%$ \\
\hline PAMPA Biome & 176,496 & $2.07 \%$ \\
\hline PANTANAL Biome & 150,355 & $1.76 \%$ \\
\hline Total Area - BRAZIL & $8,514,877$ & \\
Source: $h$ http://www.ibge.gov.br/home/presidencia/noticia/noticia_visualiza.php?id_noticia-169
\end{tabular}

This space is occupied by a population of more than 190 million habitants, with an urban concentration in the order of $85 \%$ of the population. This territory is divided into 5,565 municipalities, of which 4,957 municipalities have less than 50,000 habitants (IBGE, Census 2010).

The high rate of Brazilian urbanization highlighted in the last four decades of the past century, generated a full order of imbalance in these cities, given that they were not prepared for a migratory movement of that order. The urban population in the 1960 Census was in the order of $45 \%$ of the total population. In a certain form, the same phenomenon that would occur in Europe during the 19th century, as a result of the industrialization process, has occurred in Brazil, and is aggravated with the installation of the agro-industry and the use of land as a reserve account.

Within this context of deep, rapid changes and of diverse situations, considering the possibility of analyzing the proposals inserted within the discussions on territorial development and the respective management process becomes particularly interesting, as a form of harmonizing the national needs of (economic, social and environmental) development with local particularities.

\section{Methodological Approach}

From a methodological point of view this study can be classified as follows:

*As to the approach, it is qualitative, for being concerned with aspects of reality that cannot be quantified, as well as centered on understanding and explaining the dynamics of social relationships.

*As to the nature, it addresses applied research, for aiming to generate knowledge for practical application, driven at the solution of specific problems.

*As to the objectives, it addresses exploratory research, for having the objective of affording greater familiarity with the problem, aimed at making the problem more explicit or building hypotheses (GERHARDT, 2009). 


\section{The contexts of sustainable development}

Usually a definition of sustainable development contemplates three contexts: economic, social and environmental.

Another two aspects are equally important and, when inserted into this definition, expand the likelihood of success within the management process for sustainability: territorial and political (SACHS, 2008).

The territorial factor lays out the space where the diagnosis of the situation must be conducted, making the understanding of the possibilities and the needs more practical.

The political factor contributes with the necessary institutional apparatus that allows the local players - Government, business and civil society - to be able to engage in an organized manner, thus maintaining each player's independence and freedom of speech, while generating a favorable environment for the articulation process.

Another aspect that must be considered in a complex environment, as previously pointed out, is the cultural factor. In a country like Brazil, cultural differences must be contemplated upon studying territorial possibilities. Amazon communities present great cultural and environmental differences when compared with communities in the south of the country, both in terms of the biome and the colonizing history, which influence local culture and must be considered and respected in a management process.

Therefore, these six contexts must be present within a process seeking the articulation of the local forces, aimed at organizing public, business and civil actions aimed at the well-being of the community as a whole.

\section{The organization of economic activities}

Understanding how the economy is organized is important to improve the process of territorial management. Traditionally, economic activities are divided into primary sectors, represented by agriculture, secondary sectors, embodying industry, and tertiary sectors or services. Dowbor ( DOWBOR, 2001c), offers us a broader vision of this division by proposing that the following form of organization be considered for any study that is made of economic processes:

*Productive activities - agriculture and husbandry, logging, fishing, mining, construction and transformation industry;

*Economic infra-structures - transports, telecommunications, energy, water and sanitation;

*Commercial and financial intermediation;

*Social services - health, education, culture, information, entertainment, urbanism, housing, social protection networks, tourism, sports, justice and security (DOWBOR, 2001b, p. 9).

This division, on emphasizing infra-structure and social services, becomes more interesting for the study and the definition of the territorial potentialities, as well as for the discussion of action priorities in the management process that will be discussed further on.

\section{Territorial governance or management}

On considering the Brazilian territorial division of 5565 municipalities, where $89 \%$ of these municipalities have less than 50,000 habitants, $85 \%$ of the population is concentrated in urban areas and there are diverse potentialities and needs based on the actual territorial extension, these studies are focused on municipal units. 
The territory as a place where people live and exercise their rights and duties is, in the definition of demographists, the contiguous space where life, production and culture are organized. This space, in the organization of modern civilization is identified in the city (SANTOS, 2008).

Problems such as the eradication of poverty and the preservation of the natural environment, despite being the focus of international discussions, as occurred in the United Nations Conference on Sustainable Development, RIO+20, could see relative advances in being addressed, if they are analyzed on a distributed basis, in compliance with local realities and needs.

This argument takes into consideration that any territory does not exist on an isolated basis and should be considering global movements, whether they be economic, social or environmental. Thinking globally, acting locally means analyzing territorial particularities aimed at development through their internal or endogenous forces.

\section{Administrative decentralization and the articulation process}

Within a democratic system, a process of administrative decentralization must hold the basic principles of changing the model of representative democracy to participatory democracy, decentralizing and reducing bureaucracy in the distribution of public funds, and also in the number of instances until they reach the local administrative units (DOWBOR, 2008).

A central Government is expected to provide the availability of basic infra-structures such as energy, roads, railroads, telecommunications, facilitated public financing, mainly for micro, small and medium-size companies, monetary, oversight and taxation policy to afford an adequate distribution of corresponding responsibilities and financial resources (DOWBOR, 2001b, 2008).

Local public authority is expected to provide the allocation of resources based on an action plan, which has been widely discussed with all the other players of society - businesses and organized civil societies.

This process depends on the understanding that participation enables the alignment of expectations, the recognition of local capacities and needs, a definition of the priorities and control in executing the developed plans. The articulation of these agents is the great challenge of local development and at times its greatest weakness (VAZQUEZ BARQUERO, 2001).

From an institutional point of view, the Federal Constitution of 1988 guarantees the formation of City Councils to allow the participation of citizens in discussions on public policies for social areas. This may be a starting point for popular engagement in defining the priorities of municipal investments, nevertheless, the articulation process must be expanded and the participation of non-governmental organizations, by being structured, can have fundamental significance in thoroughly debating this discussion. Civil society organizations (CSO or NGO) have held an important role in reducing the social problems instilled by strong, disordered urbanization engaged in areas where the public sector and private business have shown to be inefficient and uninterested respectively. The proximity with local reality, the awareness of society's most urgent demands and the fact of being relatively well structured in functioning as networks of information and of the dissemination of knowledge, make these organizations important agents that assist in the formulation of public policies and actions within the territory.

Businessmen must also be stimulated to participate, since the teaching structure contributes in preparing the workforce. The existence of financing, with appropriate rates, is of fundamental importance for modernizing and expanding production, in addition to other factors of 
interest, such as infra-structure, health and other social services, which contribute towards the territory's business competitiveness.

Equally important is the political forth comings of local governing officials, which is fundamental in this process. They are in charge of orchestrating this entire movement, in order to give coherence and realism to these actions, given the existing budgetary limitations (DOWBOR, 2001c).

Dowbor further emphasizes that:

"Reinforcing the local capacity of government is necessary, but not enough, for minimally coherent public management. The required change involves a profound alteration in the administrative political culture. The difference, in our vision, is that a participatory society organized around its own interests - and local interest is a powerful organizer of citizenship - becomes a strong stabilizer of the central government itself and of the processes of international regulation, which we need" (DOWBOR, 2001c, p.30).

Reinforcing the thought that a participatory democracy does not substitute the responsibilities of the elected governing officials, Paul Singer points out that:

\begin{abstract}
"A participatory democracy does not oppose formal representative democracy and does not even intend to substitute it. Participatory democracy incorporates representative democracy, complementing it with direct democracy - consulting, plenary assembles - whenever possible and multiplying specific representative instances, in which a full diversity of interests and ideologies may be presented, debated and negotiated or, eventually, pre-negotiated, since final decisions must be made in more generally elected instances" (SINGER, 1998, p.125).
\end{abstract}

\title{
7 The challenge of planning
}

The transition from a central model of decision-making to a participatory model, in search of sustainable development, contemplates the need of knowing how to manage crises, since a simple alteration of the model, opting for the mobilization of those resources within the territory, through the modernization of the productive processes and the rendering of services, may generate imbalances in the allocation of human resources, causing an effect opposite of that desired, which is an expansion of the job opportunities and the generation of income (SACHS, 2008).

This transition process requires the application of a model of progressive change, which must make good use of the technological context existing within the territory, working on organizational improvements through business training and structural changes in the productive process, introducing innovations to the measure that employment is expanded. This model of endogenous development attends the objective of productive efficiency, required to increase competitiveness, giving emphasis to social dimension (VAZQUEZ BARQUERO, 2001).

This process is denominated by Sachs as the use of "adequate technologies", which harmonizes the best use of installed capacity in the local production sector with maintenance and, whenever possible, an extension of the work and income offered. Particular attention must be given to those products denominated "unmarketable", which are products within the territory that do not depend on imported resources, in addition to not suffering strong pressure from outside competition. Examples of perishable products are home building, local infra-structure and services that allocate more of the workforce (SACHS, 2008).

Stimulus for family agriculture must also be considered, with the creation of green belts within municipalities, providing the local populations with produce at lower prices, given a cost reduction in transport and storage, and if adequately orientated, offer products of superior quality. 
Orientation must be directed at eliminating the use of agrochemicals on planting products and economical forms of irrigation, thus contributing in the generation of work and income, safe nourishment and helping to preserve the natural environment (DOWBOR, 2008). The Social Technology Network offers a series of low cost models that allow for this type of production. Another example is the Bank of Brazil Foundation, which also presents experiences of social technologies already viably operationalized and offers textbooks orientating their implantation.

Dowbor restates the urban-rural relationship in the following way:

"Cities, on the other hand, have to be put back into the rural space where they belong. As such, it would be more accurate to speak of local space than of urban space. In the excitement of recent urbanization, a human being forgets to what point he is bound to the fields surrounding cities, and one essential element of urban development will be the reconstruction of urban-rural relations, no longer based on the fields, as in the classic vision of agrarian reform, but based on the city itself" (DOWBOR, 2001a, p.23).

Local business, particularly micro, small and medium companies (companies with as many as 49 employees were responsible for 39\% of people employed in Brazil in 2009 - IBGE, General Business Registry), can be strengthened by several initiatives. Organizational restructuring requires an increase of administrative capacity, the productivity of innovation and the competitiveness of building a network where companies work on a complimentary basis and when they are competitive, by participating in collective purchasing and promoting their products in an organized manner, constantly seeking economies of scale (SACHS, 2008, ALBUQUERQUE LLORENS, 2001).

In Barquero's vision, there is a "set of initiatives that incentivize the rise and expansion of immaterial factors and qualitative aspects in local development. Then those measures will be included, which fall upon the qualification of human resources, technological and innovative know-how, technological disclosure, entrepreneurial capacity, information about organizations and companies and the culture of development that is embedded in the population" (VAZQUEZ BARQUERO, 2001, p. 202).

Along this line, it is worth underscoring the contribution that can be given by SEBRAE (Brazilian Small Business Support Service) in forming Local Productive Arrangements. The creation of a Local Development Agency, aimed at organizing needs and monitoring action plans, can also contribute towards the evolution of those immaterial and qualitative factors mentioned above.

The need of financing for local productive activities is not at all immaterial and is, without a doubt, a great challenge in the management process.

Recalling the Brazilian territorial division, 5565 municipalities, presents the challenge of knowing how to get financial resources to reach all these locations, with adequate costs, to foment the previously discussed productive activities. Private banks, when present, operate in a manner that is disconnected from local needs. Local savings are not reused within the actual territory. Interest rates disenable the process of modernizing local companies leaving them hardly competitive. The initiatives of small entrepreneurs become unfeasible and the business mortality rate can increase. There are a few positive experiences in forming municipal banks, credit unions and even the issue of a local currency and these may be a pathway to solving such a complex problem (DOWBOR, 2001b, 2008).

The existence of Development Agencies can also contribute towards the organization of these demands, by supporting local initiatives in the search of financing existing within governmental areas or even at BNDES (Brazilian Development Bank. 
If duly organized productive activities sustainably contribute towards territorial development, social services can be used as leverage in the process of generating work and income on two fronts.

On first hand, areas such as education, health, transport, security, leisure, housing, infrastructure, sports and culture hold a strong allocation of the workforce as an essential characteristic. On the other hand, in order for quality services to exist, this contingent of the workforce requires specialized training, which leads to higher wage compensation.

Second of all, the perennially and competitiveness of productive activities directly depend on the quality of social services offered to the population. Examples can be stated such as education, in training the workforce, health, in reducing absences at work, originating from sickness, transport, facilitating access to companies, security, sport, leisure and culture generating the increased satisfaction of the population and greater productivity at work. As a result, a virtual circle of development is created, with social inclusion and a consequent increase in feelings of belonging (DOWBOR, 2001c, 2008).

Articulating the whole of society in the diagnosis and enabling ways they can improve their quality of life can be a great facilitator in the discussion on environmental issues inherent to the productive processes, as well as in the creation of management processes for existing natural resources. Despite the need for this discussion to occur on a global basis, in UNO sponsored forums, the problems are originated locally. If the principals of environmental education, corporate social responsibility and natural environment preservation have been discussed in each municipality, the possibilities of global targets being met become more promising.

Vasquez Barquero underscores that the structuring of territorial development policies reinforces the ecological dimension, for these give more emphasis to qualitative than to quantitative aspects of development, and complements:

\footnotetext{
"the preservation of the natural environment is a source of opportunities in creating companies and jobs. The proposals of the last generation (of policies) stimulate ecological agriculture - producing products that are increasingly demanded more at higher income levels -, feed urban and rural tourism - which attract travelers and tourists and help to conserve historical and cultural treasures and the natural environment -, generating research activities and the production of renewable energy and create activities for services and technical assistance, centered on the preservation of the natural environment" (VASQUEZ BARQUERO, 2001, p.243).
}

\section{Organization of information - transparency within the process}

A participatory management process requires transparent organization and the availability of information on a level playing field. This information will be posted at two moments of the processes: firstly as form of obtaining a map of the municipality's situation in all of its activities, orientating the definition of priorities and the planning of actions and secondly for accompanying the defined plans and the main indicators of results.

The set of information made available by central authorities, quite often, appears to be structured on an aggregated basis and is not transformed as useful information for action in local processes. Furthermore, results if an exclusive economic order do not attend the needs of information as a strategic tool for local planning (ALBUQUERQUE LLORENS, 2001). 
The availability of information, with the revolution in information and communication technologies (ICT), has become much simpler and cheaper. The possibility of a municipality setting up its own telecommunications system at a relatively low cost will assist digital inclusion, placing an ordinary citizen in touch with the world, will contribute with local companies towards internet access at reduced prices, and will provide a modernization of the administrative machine. Setting up a database for the actual municipality does not require sophisticated tools and such disclosure complies with the democratization of information, essential in the process of articulation and of stimulating participation (DOWBOR, 2001c, 2008).

In Brazil, IBGE detains a great deal of information already organized by municipality, and other information that can be obtained from the Ministries. Furthermore, initiatives such as the ODM Portal - Municipal Accompaniment of Millennium Development Goals - are made available important indicators on all Brazilian municipalities.

In 2005/2006, the Instituto Cidadania developed a National Policy Project for Supporting Local Development introducing eight axis areas in formulating policies, divided as follows: financing and marketing; technology; institutional development; information; communication; education and training; work, employment and income; and environmental sustainability. This project presents a diagnosis on the situation of each axis area and offers proposals in forwarding solutions for problems encountered.

Interesting experiences may also be consulted such as those at Rede Nossa São Paulo (Sao Paulo Network) and at Câmara do Grande ABC (ABC Chamber) which are structured on the axis areas and offer a series of development indicators. The Instituto Pólis, which gives great emphasis to local development, at its electronic address, offers a manual of Tips for City Actions, where very successful experiences, on several topics of interest to the local players and to the articulation process, may be located.

In light of the scenario exemplified above, it might be said that from an informational point of view, the Brazilian situation shows to be highly promising for the process of identifying needs. However, the importance of structuralizing, the availability of information on action plans and their respective indicators must be emphasized.

\section{Development of Large cities}

Large cities and, mainly, the metropolises present particularities that make their development process sustainably more challenging. The influence of metropolises has altered according to the diverse moments of Brazilian history from, at first, being responsible for commanding the territories and their surroundings, structuring social, political and economic organization according to the determinations of the central Government to, in changing with the process of globalization, primordially serve the hegemonic interests of large national and international organizations, which have come to command these territories with the support of the Government (SANTOS, 2008).

This phenomenon occurs throughout the world, transforming metropolises into the mega-knots of a giant global network, converging points for capital, specialized workforces, processes of innovation and power (CASTELLS, 1999). The power of these transnational organizations is presented in a study from the Swiss Federal Institute of Technology, which is analyzed by Dowbor in an article regarding the network of worldwide corporative power.: 
"The Swiss Federal Technology Institute (ETH) of Zurich published the first map of the network of global corporate control, a contribution of first-rate importance. This basically shows that 737 groups control $80 \%$ of the universe of large transnational corporations, of which $40 \%$ is controlled by a hard core of 147 corporations that are almost all financial corporations" (DOWBOR, 2012).

These forces, studied by Milton Santos, are foreign to local reality and its needs, thus creating great disparities in terms of the distribution of benefits. Municipal investments are centered on services in their own interests, marginalizing everything that does not give them direct returns, causing dramatic situations in these large centers where local power has enormous difficulties in articulating and establishing policies that promote ample rearrangement and development, creating wealthy areas and shanty towns within the same physical environment. According to Milton Santos, "this is the great damnation of the contemporary metropolis" (SANTOS, 2008, p.73).

Data from the 2010 Census show the following reality in terms of large urban agglomerates:

* Metropolitan Regions and Regions of Integrated Economic Development (RIDES) concentrate a population of around 90 million habitants.

*When municipalities are classified by population size, 38 municipalities with more than 500,000 habitants are encountered, amounting to a total population of about 56 million habitants.

The vision of this population concentration serves to provide the dimension of those challenges inherent to managing these spaces. The logic of processes seeking sustainable development can be considered the same, however, the organization articulation and planning processes will require greater effort and creativity.

\section{Applications to the Metropolitan Regions' case}

The metropolitan areas were regulated by federal law and current units defined by Brazilian states. According to the IBGE, in 2012, 36 metropolitan areas are distributed in 20 states and 3 RIDES - Development Integrated Regions, which comprises 6 different states and the federal district.

The MRs were created in the 1970s, when a disorganized development in large cities happened. Great migratory flow created big production regions with immense wealth and social inequality, the impoverished periphery. In the following decades, surrounded cities of the metropolis passed also by a large population growth, given rise to metropolitan area growth.

The Federal Constitution of 1988 valued the municipal jurisdiction in solving local problems, delegated to the states the assignment of establishing metropolitan areas, urban agglomerations and micro-regions, and managing intercity problems.

With regional differences metropolitan areas and Rides took different configurations in each reality, hampering the development of policies that promote sustainability in the region as a whole. 
The creation of the Ministry of Cities, the incentive to associated administration and the establishment of public consortium law, strengthened the cooperation between federal units, but despite policies to encourage the cooperative work among federal entities, little has been done, because there are definitions that need to be taken to encourage the collaborative process.

According to a study conducted by UN-HABITAT the 25 majors MR will have population $10 \%$ higher in 2025, 92 million inhabitants, with the major growth will occur in the northeast, where the lack of infrastructure is higher.

The challenges need to be faced and medium and long term policies have to overlap the short-term thinking, predominant action in public administration in the country.

\section{Final considerations}

Territorial development has been presented as one of the most promising alternative forms to the traditional model of public management in municipalities.

As observed, a process of local management is initiated by administrative decentralization, which leads this discussion to consider that all the other levels of - state and federal - government must provide a flow of resources to municipalities in proportion to the responsibly. Even without considering that this first phase amply, very successful, the next step is put emphasis on the articulation of the local players, Government, business and civil society, aimed at migrating from a representative democracy to a participatory model.

In this system of participatory management, the organization of demands within a planning process, discussing the existing capacities, the potential of developing new activities, the natural resources, the situation of the natural environment, the business structure, in organizational and technological terms, the agricultural structure, the scenario of local infra-structures as well the situation of public services and the budgetary reality of that municipality, must generate action plans that will form a set of initiatives, understood to be priorities by local society as a whole, in search of local sustainable development.

As Dowbor points out, despite the need of participation from all agents, the orchestration of the process by local governments is of fundamental importance in order for all these interests to be harmonized with the real potentialities, capacities and interests within each municipality and for the process of effectively managing action plans to exist with the facilitated availability of information, thus stimulating the continuity and expansion of the participatory process. Vazquez Barquero warns that, in the process of participatory management, articulation becomes the main challenge and, at times, the greatest weakness, but also recalls that, upon attaining conditions that allow the process to progressively advance, territorial development, by privileging local resources and capacities, carries in itself a unique social dimension.

Finally, it's important to consider that there is a significant volume of information in Brazil, both in terms of structural data as well as accumulated experiences, available for local agents for the purpose of territorial sustainable development management. 


\section{References}

[1] ALBUQUERQUE LLORENS, Francisco Desenvolvimento econômico local: caminhos e desafios para a construção de uma nova agenda política, Rio de Janeiro: BNDES, 2001.

[2] AZEVEDO, Heloisa Pereira Lima, ALVES, Adriana Melo Rides - por que cria-las? Belo Horizonte: Geografias 06(2) 87-101 julho-dezembro de 2010

[3] Arranjos Produtivos Locais, SEBRAE, http://www.sebrae.com.br/customizado/desenvolvimento-territorial, acessado em 13/03/2012.

[4] Biomas Continentais Brasileiros, http://www.ibge.gov.br/home/presidencia/noticias/noticia_visualiza.php?id_noticia=169, acessado em 13/03/2012.

[5] Boletim Dicas, Ideias para Ação Municipal, Instituto Pólis, http://www.polis.org.br/?/institucional/catalogo-de-publicacoes-polis, acessado em 18/03/2012.

[6] Câmara do Grande ABC - http://www.consorcioabc.sp.gov.br/institucional, acessado em 16/03/2012.

[7] CASTELLS, Manuel A sociedade em rede, vol.1, São Paulo: Paz e Terra, 1999.

[8] DOWBOR, Ladislau A Reprodução Social, vol.1, 2001a, disponível em dowbor.org, acessado em 03/08/2011.

[9]

A Reprodução Social, vol.2, 2001b, disponível em dowbor.org, acessado em 03/08/2011.

[10] 03/08/2011.

A Reprodução Social, vol.3, 2001c, disponível em dowbor.org, acessado em O que é poder local? , 2008, disponível em dowbor.org, acessado em 03/08/2011. A rede do poder corporativo mundial, 2012, disponível em dowbor.org, acessado em 08/072012.

[13] GERHARDT, Tatiana Engel, SILVEIRA, Denise Tolfo Métodos de Pesquisa, Porto Alegre: Editora UFRGS, 2009.

[14] IBGE Censo 2010, Sinopse, http://www.sidra.ibge.gov.br/cd/cd2010sp.asp?o=3\&i=P , acessado em 10/07/1012

[15] Portal ODM Acompanhamento Municipal dos Objetivos de Desenvolvimento do Milênio, http://www.portalodm.com.br/, acessado em 16/03/2012.

[16] Projeto Política Nacional de Apoio ao Desenvolvimento Local, disponível em dowbor.org, acessado em 03/08/2011.

[17] Quantidade de Empresas e Pessoal Ocupado por Região, Cadastro Geral de Empresas, IBGE, www.ibge.gov.br, acessado em 08/09/2011.

[18] Rede Nossa São Paulo - http://www.nossasaopaulo.org.br/portal/, acessado em 1603/2012.

[19] SACHS, Ignacy Desenvolvimento includente, sustentável, sustentado, Rio de Janeiro: Garamond, 2008.

[20] SANTOS, Milton Técnica, Espaço, Tempo: Globalização e Meio Técnico-científico-informacional, São Paulo: Editora da Universidade de São Paulo, 5a ed., 2008.

[21] SINGER, Paul Desafios com que se defrontam as grandes cidades, in SOARES, José Arlindo, CACCIA-BAVA, Silvio (ORGS) Os desafios da gestão municipal democrática, São Paulo: Cortez, 1998. 
[22] TEIXEIRA, L. Consórcios intermunicipais: instrumento para aumentar a eficiência do gasto público. In: M. Mendes (Org.). Gasto Público Eficiente: 91 Propostas para o Desenvolvimento do Brasil. São Paulo: Instituto Fernand Braudel/Topbooks, 2006.

[23] United Nations Human Settlements Programme (UN-HABITAT); State of the world's cities Prosperity of Cities

[24] VAZQUEZ BARQUERO, Antonio Desenvolvimento endógeno em tempos de globalização, Porto Alegre: Fundação de Economia e Estatística, UFRGS, 2001. 